Webbia

Journal of Plant Taxonomy and Geography

\title{
Studies on Potheae of Borneo I: Pothos pugnax, a new species of Pothos [Allopothos: Pothos barberianus group] from Kuching Division, Sarawak, Malaysian Borneo
}

\section{Sin Yeng Wong \& Peter C. Boyce}

To cite this article: Sin Yeng Wong \& Peter C. Boyce (2019): Studies on Potheae of Borneo I: Pothos pugnax, a new species of Pothos [Allopothos: Pothos barberianus group] from Kuching Division, Sarawak, Malaysian Borneo, Webbia, DOI: 10.1080/00837792.2019.1639107

To link to this article: https://doi.org/10.1080/00837792.2019.1639107

曲 Published online: 18 Jul 2019.

Submit your article to this journal \lceil

ЏII Article views: 2

View Crossmark data \lceil 


\title{
Studies on Potheae of Borneo I: Pothos pugnax, a new species of Pothos [Allopothos: Pothos barberianus group] from Kuching Division, Sarawak, Malaysian Borneo
}

\author{
Sin Yeng Wong ${ }^{\mathrm{a}, \mathrm{b}}$ and Peter C. Boyce ${ }^{\mathrm{c}}$

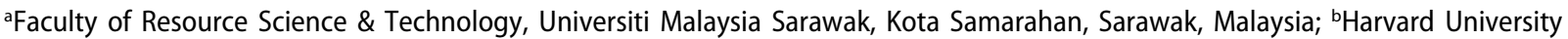 \\ Herbaria, Cambridge, MA, USA; 'Department Biologie I, Systematische Botanik und Mykologie, Ludwig-Maximilians-Universität \\ München, München, Germany
}

ABSTRACT

Pothos pugnax is described and illustrated as a new species [Allopothos supergroup: Pothos barberianus group] from ridgetop kerangas in Kuching Division, Sarawak, Malaysian Borneo. Comparison is made with Pothos atropurpurascens the only closely similar species occurring on Borneo, and also between the confoundable shingling stages of $P$. pugnax and the parapatric but distantly related Pothos beccarianus [Goniurus supergroup].
ARTICLE HISTORY Received 24 May 2019 Accepted 30 June 2019

KEYWORDS

Borneo; Araceae; Pothos; Potheae; kerangas

\section{Introduction}

Pothos L. is a genus of about 60 species of largely nomadic vines (Zotz 2013) distributed from Madagascar to the tropical western Pacific and from the subtropical Himalayas and western China to subtropical north-east Australia. Although revised for much of its range (Nicolson 1988; Hay 1995; Boyce 2000, 2009; Boyce and Hay 2001; Li et al. 2010; Boyce et al. 2012; Nguyen et al. 2017), there remain large gaps in understanding of the taxonomy and, inevitably, the distribution of the individual species, nowhere more so than for Borneo, one of several centres of species diversity. As usually the case with Asian climbing aroids, many of the taxonomic inexactitudes are results of poor-quality herbarium material, and imperfect types. Pothos affords additional components to these difficulties in that, with a few exceptions (i.e. Pothos chinensis (Raf.) Merr. P. scandens L., P. tener Wall.), most species appear to be genuinely uncommon in the wild and furthermore plants are seldom encountered flowering, indeed most species give the impression of flowering rather infrequently in nature. As may be judged from the foregoing, and given that a substantial component of the published accounts was prepared from herbarium material alone, much remains to be done.

Over the last almost two decades of fieldwork on Borneo, although dutifully examining any Pothos encountered in anticipation of flowering material, no concerted effort has been made to work on the genus, despite us being aware of shortcomings in the published account covering Borneo (Boyce and Hay
2001). The patchiness of our understanding was brought sharply into focus during fieldwork on a hill well known to us, during which we encountered on a track-side tree a remarkable Pothos with stiffly spreading fertile branches held at head height and carrying sharply pendent blooms comprised of a large white cucullate spathe and a glossy deep purple spadix, the combination of which immediately marked it as being undescribed.

Floral terminologies used this paper differ intentionally from those of previous papers on the genus Pothos and are intended to pave the way to interpreting the 'inflorescence' of Pothos, and of all other aroids, as a unique structure that is neither a flower nor an inflorescence as defined by current prevailing orthodoxy. For the background to this conceptual change, see Hay (forthcoming), Hay and Mabberley (1991) and Mabberley and Hay (1994). It will be additionally noted that we employ Zotz's term nomadic vine rather than, as previously, secondary hemiepiphytes in describing the lifeform of Pothos. See Moffett (2000) and Zotz (2013) for the background to this change of terminology.

Subordinal classifications used follow Boyce and Hay (2001, p. 454-455).

Geological occurrences in this paper are verified using Tate (2001).

Pothos pugnax P. C. Boyce \& S. Y. Wong, sp. nov.

Type: Malaysia, Sarawak, Kuching, Bau, Kampung Segong, trail to Gunung Moi, $1^{\circ} 32^{\prime} 8.83^{\prime \prime} \mathrm{N} 110^{\circ}$ 9'31.261"E, 55 m asl, 8 November 2017, P. C. Boyce, 